\title{
Type of corn and grinding degree in a concentrate supplied to suckling calves $^{1}$
}

\author{
Cibele Santos Ferreira ${ }^{2}$, Fabiano Ferreira da Silva ${ }^{3}$, Cristina Mattos Veloso ${ }^{4}$, Paulo Bonomo ${ }^{3}$, \\ Julinessa Silva Oliveira ${ }^{2}$, Vinícius Lopes da Silva ${ }^{2}$, Alex Resende Schio ${ }^{2}$, Luís Carlos Vínhas Ítavo ${ }^{5}$ \\ 1 Projeto financiado pelo CNPq. \\ 2 Programa de Pós-graduação em Zootecnia, Universidade Estadual do Sudoeste da Bahia - UESB, Itapetinga, BA, Brasil. \\ ${ }^{3}$ Departamento de Tecnologia Rural e Animal, UESB, Itapetinga, BA, Brasil. \\ ${ }^{4}$ Departamento de Zootecnia, Universidade Federal de Viçosa - UFV, Viçosa, MG, Brasil. \\ 5 Departamento de Zootecnia, Universidade Católica Dom Bosco - UCDB, Campo Grande, MS, Brasil.
}

\begin{abstract}
The objective was to assess the effects of a concentrate consisting of two types of corn: flint and dent, with three different grinding degrees $(1,3$ and $5 \mathrm{~mm}$ ), as a function of intake, performance and digestibility of three crossbred dairy suckling heifers. A randomized block design involving 54 crossbred heifers in a $2 \times 3$ factorial arrangement was used to assess intake and performance patterns. In order to assess digestibility, the experimental design was completely randomized, consisting of 24 crossbred heifers. Weighting and measurements of height at withers and thoracic perimeter were performed. There was no significant interaction between grinding degree and corn type for any of the studied variables. The daily intake of concentrate dry matter was higher for flint corn (243 g/day) as compared with dent corn (160 g/day). The grinding degree caused difference in the dry matter, crude protein and ether extract intake, with higher intake when 3 and 5 mm sieves were used in the process. There was no difference regarding average daily gain and increased withers, croup and thoracic perimeter. Likewise, feed conversion did not differ. Regarding dry matter digestibility, there was an effect resulting from the hardness of corn $(78.9 \%$ for dent, and $84.3 \%$ and for flint corn). As for the grinding degree, the highest value of dry matter digestibility was found when using $5 \mathrm{~mm}$ sieves (84.2\%), whereas the percentage values found for $1 \mathrm{~mm}$ and $3 \mathrm{~mm}$ mesh sieves were $79.1 \%$ and $78.1 \%$, respectively. It is recommended that heifer calves in the early stage of growth be fed flint corn ground through 3 or $5 \mathrm{~mm}$ mesh sieves.
\end{abstract}

Key Words: dent corn, early weaning, flint corn, initial concentrate

\section{Introduction}

The advancement of feeding and management techniques in dairy farming - particularly related to calf rearing - has led farmers to seek cost-effective alternatives to such exploitation.

Calves breastfed for long periods consume excessive amounts of milk and therefore increase feed costs. By introducing early solid feed intake, it becomes possible to raise calves with a controlled supply of milk (Campos, 2000).

According to Pires et al. (2008), starch stands for 70$80 \%$ of dry matter in most grains and is the primary energy source in diets formulated for heifers. Improving the use of starch is essential to optimize the development of heifers.

Corn grain can be classified according to its hardness. The endosperm of the grain (region in which the starch granules are located) is divided into two parts of similar composition with regard to crude protein and starch, but quite distinct from the perspective of physical structure, which can be vitreous or mealy. Corn grain usually has two endosperm types, and their ratio is the major factor defining the hardness of grains (Phillippeav \& Michalet-doreau, 1997).

From the grain endosperm, one can divide corn hybrids into two main categories: dent or soft corn (the predominant endosperm is mealy or porous) and flint or hard corn (the predominant endosperm is vitreous or hard).

Although no difference has been detected in some cases (Santos et al., 2007; Pires et al., 2008), studies involving lactating cows have found advantages of fine grinding over coarse grinding (Nussio et al., 2002; Dhiman et al., 2002).

A few years ago, the supply of processed concentrates to suckling calves was thought to be essential (laminate, pelletized, flaked, etc.), but new studies have found that different densities (283 g/L, $360 \mathrm{~g} / \mathrm{L}, 437 \mathrm{~g} / \mathrm{L}$ ) of flaked corn resulted in similar performance (Bagaldo et al., 2001) and that the type of grain processing (flaked corn vs. rolled corn) did not affect the performance of heifers (Nussio et al., 2003); likewise, the physical form of the concentrate (mash or pellets) did not influenc intake or performance of suckling heifers (Bittar et al., 2009). Thus, the supply of non-processed 
grains in the concentrate can be an alternative to reduce production costs.

Therefore, the objective of this study was to evaluate the use of flint and dent corn at different grinding degrees ( 1,3 or $5 \mathrm{~mm}$ ) in feed formulated to crossbred dairy heifers, as well as its effects on intake, digestibility and productive performance.

\section{Material and Methods}

The experiment was conducted in Paulistinha Farm, located in the city of Macarani-BA, and chemical analyses were performed at the Laboratory of Forage Crops and Pasture of Universidade Estadual do Sudoeste da Bahia, Itapetinga-BA, Brazil.

A total of 54 crossbred heifers (blood level ranging from $1 / 4$ to $1 / 2$ Dutch) aged seven days and whose initial weight was $31.29 \pm 0.67 \mathrm{~kg}$ were used. The animals were housed in individual wooden shelters covered with asbestos tiles and equipped with individual feed troughs and $30 \mathrm{~L}$ plastic drinkers.

Two corn types (flint and dent) and three grinding degrees (milled through 3 and 5 mm mesh sieves) in a $2 \times 3$ factorial arrangement were assessed.

The dent corn used was from the cultivar AG 1051, whereas the flint corn was purchased at livestock stores and was specific of no cultivar. Both corn types were milled in 1,3 and $5 \mathrm{~mm}$ mesh sieves; milled samples were subjected to retention tests in sieves (Table 1).

Heifers were set aside from their mothers 24 hours after birth, beginning then a seven-day adaptation period. From the first milking, 2 liters of colostrum were provided during the first 6 hours of life and another 2 liters within the first 24 hours; after the second day of life, four liters of milk were provided daily. After the adaptation period, 4 liters of milk were provided daily in 2-liter plastic bottles (two liters at 7.00 a.m. and two liters at 4.00 p.m.) and water was provided ad libitum; in turn, mash concentrate was given according to the treatment. The troughs were filled daily and leftovers were weighed and sampled once a week. The experimental period was initiated as the animals were seven days old, lasting 53 days; animals were weaned at 60 days of life.

Table 1 - Proportion of material (\%) retained on 2, 3 and 5 mm sieves

\begin{tabular}{ccccc}
\hline & \multicolumn{4}{c}{ Sieves $(\mathrm{mm})$} \\
\cline { 2 - 5 } Grinding $(\mathrm{mm})$ & 5 & 3 & 2 & Bottom \\
\hline 1 & 0.01 & 0.87 & 11.0 & 88.30 \\
3 & 0.60 & 13.53 & 23.27 & 62.60 \\
5 & 5.63 & 33.26 & 19.53 & 41.66 \\
\hline
\end{tabular}

The concentrates were formulated based on the requirements recommended by the NRC (2001) so as to allow a daily weight gain of $400 \mathrm{~g}$ (Table 2).

The following concentrate contents were assessed: dry matter (DM), mineral matter (MM), total nitrogen (TN), ether extract (EE), neutral detergent fiber (NDF) and acid detergent fiber (ADF), following the techniques described by Silva \& Queiroz (2002); crude protein (CP) was obtained by the product resulting from total nitrogen content and the 6.25 factor for concentrates (Table 3). The NDF content was corrected for neutral detergent insoluble protein (NDIP) and neutral detergent insoluble ash (NDIA), using the equation NDFap = NDF - $($ NDIP+NDIA $)$; all terms were expressed in \% of DM (Detmann et al., 2008). Nonfibrous carbohydrates (NFC) were obtained by the equation $\mathrm{NFC}=100-(\mathrm{CP}+\mathrm{EE}+\mathrm{MM}+\mathrm{NDFap})($ Detmann $\&$ Valadares Filho, 2010).

Milk samples were collected weekly and analyses of fat, moisture and crude protein (Table 3) were performed; the latter was obtained by the product between total nitrogen content and the factor 6.38 , according to the methodology described by the AOAC (1990).

In view of assessing performance data, body weighing and measurements of wither and croup heights, as well as thoracic perimeter, were performed on the first, 30th and 60th days of life.

Digestibility was assessed on the five days subsequent to the trial period so as not to interfere with the assessment of other variables; then, heifers continued to be fed four liters of milk plus concentrate - according to the respective treatment - so as to evaluate digestibility until reaching 65 days of life. For the digestibility assay, 24 calves were used in a completely randomized design and the collection of stool samples was performed using collection bags. Stools were collected twice and weighed each day, in the morning and late afternoon; after five days, a composite sample was made with a sampling proportional to five days. Chemical analyses were performed to the same done to concentrate.

Table 2 - Concentrate ingredients

\begin{tabular}{lc}
\hline Ingredient & g/kg of dry matter \\
\hline Milled corn grain & 460.8 \\
Soybean meal & 392.3 \\
Wheat meal & 94.5 \\
Mineral salt ${ }^{1}$ & 40.0 \\
Sodium bicarbonate & 10.0 \\
Calcitic limestone & 2.4 \\
\hline${ }^{1}$ Composition: Ca - 233 g/kg; P - 80 g/kg; Mg - 5 g/kg; Na - 48 g/kg; Co - $25 \mathrm{mg} / \mathrm{kg} ;$ \\
Cu - 380 mg/kg; - 25 mg/kg; Mn - 1080 mg/kg; Se - 3.75 mg/kg; Zn - $1722 \mathrm{mg} / \mathrm{kg}$; \\
vitamin A/kg - 300.000 U.I; vitamin D/kg - 55.000 U.I.
\end{tabular}

R. Bras. Zootec., v.41, n.6, p.1484-1489, 2012 
Table 3 - Chemical composition of concentrates, milk and corn types

\begin{tabular}{|c|c|c|c|c|c|c|c|c|c|}
\hline & \multicolumn{6}{|c|}{ Concentrate } & \multirow[t]{2}{*}{ Milk } & \multicolumn{2}{|c|}{ Corn } \\
\hline & Dent1 & Dent3 & Dent5 & Flint5 & Flint5 & Flint5 & & Dent & Flint \\
\hline $\mathrm{DM}^{1}$ & 857 & 875 & 876 & 892 & 882 & 889 & $104 \pm 4.7$ & 884 & 896 \\
\hline$C P^{2}$ & 284 & 279 & 308 & 276 & 280 & 316 & $288 \pm 7.7$ & 94 & 107 \\
\hline $\mathrm{EE}^{2}$ & 43 & 34 & 36 & 43 & 33 & 24 & $346 \pm 6.7$ & 35 & 36 \\
\hline $\mathrm{NDF}^{2}$ & 285 & 280 & 273 & 332 & 305 & 306 & - & 324 & 320 \\
\hline $\mathrm{ADF}^{2}$ & 178 & 159 & 167 & 191 & 163 & 175 & - & 127 & 104 \\
\hline $\mathrm{MM}^{2}$ & 85 & 92 & 82 & 85 & 87 & 82 & - & 13 & 14 \\
\hline $\mathrm{NFC}^{2}$ & 301 & 313 & 300 & 261 & 293 & 270 & - & 492 & 465 \\
\hline
\end{tabular}

DM - dry matter; CP - crude protein; EE - ether extract; NDF - neutral detergent fiber; ADF - acid detergent fiber; MM - mineral matter; NFC - non-fibrous carbohydrates. $1 \mathrm{~g} / \mathrm{kg}$ of natural material.

$2 \mathrm{~g} / \mathrm{kg}$ of dry matter.

The test for comparison of means of least squares was applied to evaluate the effects of corn hardness and grinding degree, as well as interactions (treatments) referring to the means of intake, performance and nutrient digestibility; a 0.05 level of significance was considered for the probability of $F$ test in the analysis of variance and in the comparison test of means by the Tukey test, using the software SAEG (Sistema para Análises Estatísticas e Genéticas, version 9.1).

\section{Results and Discussion}

The milk DM intake during the experimental period was $419 \mathrm{~g} /$ day. There was no significant interaction $(\mathrm{P}>0.05)$ between corn type $\times$ grinding degree for daily intake of $\mathrm{DM}$. As for the means of daily dry matter intake of concentrate, there was an effect $(\mathrm{P}<0.05)$ resulting from the interaction between corn type and grinding degree (Table 4). Heifers consumed more concentrate containing flint corn (243 g/ day) than that containing dent corn (164 g/day). The $5 \mathrm{~mm}$ grinding degree brought about greater intake for calves fed concentrates ( $237 \mathrm{~g}$ /day) as compared with the $1 \mathrm{~mm}$ degree (162 g/day), yet no difference was observed for the $3 \mathrm{~mm}$ grinding degree (212 g/day).

For an average lactation period of 60 days, the intake of concentrate was below the $300 \mathrm{~g} /$ day expected, according to Bittar et al. (2009). The possible causes of low intake of concentrate could not be detected in this experiment. Heifers possibly underwent some level of heat stress, as the

Table 4 - Mean daily intake of DM (g/day) of concentrates from 7 to 60 days of life and coefficient of variation (CV)

\begin{tabular}{lcccc}
\hline Type of corn & \multicolumn{3}{c}{ Grinding degree } & Mean \\
\cline { 2 - 4 } & 1 & 3 & 5 & \\
\hline Dent & 138 & 167 & 186 & $164 \mathrm{~B}$ \\
Flint & 187 & 256 & 288 & $243 \mathrm{~A}$ \\
Mean & $162 \mathrm{~b}$ & $212 \mathrm{ab}$ & $237 \mathrm{a}$ & 204 \\
CV \% & & 18.58 & & \\
\hline
\end{tabular}

Means followed by different uppercase letters in the column and lowercase letters in the rows differ $(\mathrm{P}<0.05)$ by $\mathrm{F}$ and Tukey tests, respectively. experiment was conducted during the hottest time of year (spring and summer); this also explains the low intake of concentrate.

According to the NRC $(1989,1996)$, DM intake can be influenced by physiological factors such as size and body composition (especially fat), production demand, sex, age, physiological stage; environmental effects such as temperature, weather, photoperiod, feed management, forage availability; and effects of diets, such as moisture content in the feed, degree of fermentation in silage, protein and processing methods.

There was no significant interaction $(\mathrm{P}>0.05)$ between corn and grinding degree for DMI and dietary nutrient means (Table 5).

Heifers consuming a concentrate containing flint corn had greater $(\mathrm{P}<0.05)$ intake of $\mathrm{DM}, 664 \mathrm{~g} /$ day, as compared with those consuming dent corn, $578 \mathrm{~g} /$ day. As a result of higher dry matter intake by calves consuming flint corn, these animals had higher intakes of CP, EE, NDF and MM than those consuming dent corn. It is therefore possible that the pulverulence of the diet exerts an effect on DM intake, since the diet with dent corn has a farinaceous endosperm as compared with flint corn, which may limit intake by calves.

No difference was found for grinding degree $(\mathrm{P}<0.05)$ and higher values were found for heifers consuming concentrate milled at 3 and $5 \mathrm{~mm}$ (657 and $651 \mathrm{~g} /$ day), as compared with $1 \mathrm{~mm}$ (582 g/day). The highest DM intake observed for coarse ground corn ( 3 and $5 \mathrm{~mm}$ ) indicates that a higher grinding degree is enough to facilitate digestion by rumen microorganisms; moreover, its better intake is possibly due to the greater ease of ingestion of feed and lower pulverulence.

Different CPI $(\mathrm{P}<0.05)$ levels were observed as a function of grinding degree: CPI was higher for grindings at 3 and $5 \mathrm{~mm}$ (190 and $205 \mathrm{~g} /$ day, respectively), as compared with grinding at $1 \mathrm{~mm}$ (173 g/day), whose value was similar to that of DMI. 
There was also a significant difference $(\mathrm{P}<0.05)$ in the grinding degree detected for EEI, with a higher value for the concentrate diet consisting of corn milled at $5 \mathrm{~mm}$ (157 g/day) and $3 \mathrm{~mm}$ (158 g/day), as compared with that consisting of corn milled in $1 \mathrm{~mm}$ mesh sieves (154 g/day).

Leismeister \& Heinrichs (2004) failed to determine differences between adult and young ruminants in their ability to use processed corn, but they found that heifers fed diets containing whole corn had better weight gain, followed by those that consumed dry-rolled corn and toasted corn; in turn, those consuming steam-flaked corn had worse weight gain.

Corn type was only observed to have an effect on NDFI and MMI, with higher values for flint corn. As the chemical composition of feed was similar (Table 3 ) and dry matter intake was greater for heifers fed a flint corn-based concentrate, the intake of all nutrients was higher in treatments containing flint corn as compared with those containing dent corn.

Flint corn led to greater TDNI $(\mathrm{P}<0.05)$ as compared with dent corn $(791 \times 667 \mathrm{~g} /$ day $)$. Grinding degree did not interfere with TDNI $(\mathrm{P}>0.05)$, with a daily mean of $729 \mathrm{~g}$ for grinding degrees of 3 and $5 \mathrm{~mm}$. This can be explained by the effect on DMI, where the flint corn had greater DMI when compared with dent corn; hence, higher TDN levels were ingested.
According to Rohr \& Daenicke (1984), body weight gain is an essential measure for estimating animal development on feeding and production systems.

There was no interaction of corn type $\times$ grinding degree (Table 6$)$. The type of corn did not affect $(P>0.05)$ the variables studied.

The average daily gain was less than expected, $284 \mathrm{~g} /$ day, probably due to the lower intake of concentrate. Aita et al. (2006) found a $470 \mathrm{~g} /$ day value for Jersey calves that weaned at 56 days of life. In a study involving Holstein calves fed milled grains in the suckling period, Schalch et al. (2001) found ADG value of $450 \mathrm{~g}$ /day for animals aged 42 days. In a study involving calves fed mashed, pelleted and textured concentrate, Franklin et al. (2003) found gains of the order of 500, 440 and $550 \mathrm{~g} /$ day, respectively. Cunha et al. (2007) found average daily gain of $471 \mathrm{~g}$ for crossbred animals aged 8 weeks fed a commercial concentrate and four liters of milk per day. It is important to mention that breed and sex can influence weight gain; then, precocious breeds such as Jersey may show lower weight due to a greater fat deposition as compared with other breeds such as the Holstein; because of hormonal differences, males may show gains up to $10 \%$ higher than females.

Results from increased wither height $(15 \mathrm{~cm}$ for dent corn and $14 \mathrm{~cm}$ for flint corn) are close to those expected for this age group when compared with data observed by

Table 5 - Mean total intake (concentrate + milk) of heifers during lactation

\begin{tabular}{|c|c|c|c|c|c|c|c|c|c|}
\hline \multirow[t]{2}{*}{ Intake (g/day) } & \multicolumn{2}{|c|}{ Type of corn } & \multicolumn{3}{|c|}{ Grinding degree } & \multirow[t]{2}{*}{ CV \% } & \multicolumn{3}{|c|}{ P-value } \\
\hline & Dent & Flint & 1 & 3 & 5 & & C & G & $\mathrm{C} \times \mathrm{G}$ \\
\hline DMI & 582B & $664 \mathrm{~A}$ & $582 b$ & $657 \mathrm{a}$ & $651 \mathrm{a}$ & 13.2 & 0.006 & 0.023 & 0.682 \\
\hline EEI & $154 B$ & $158 \mathrm{~A}$ & $154 b$ & $158 a$ & $157 a$ & 2.1 & 0.002 & 0.038 & 0.988 \\
\hline NDFI & $52 \mathrm{~B}$ & $86 \mathrm{~A}$ & 58 & 71 & 78 & 42.4 & 0.001 & 0.090 & 0.684 \\
\hline MMI & $16 \mathrm{~B}$ & $23 \mathrm{~A}$ & 16 & 21 & 22 & 41.4 & 0.001 & 0.055 & 0.682 \\
\hline NFCI & 190 & 201 & 183 & 199 & 205 & 15.8 & $<0.001$ & 0.081 & 0.728 \\
\hline
\end{tabular}

Means followed by different uppercase letters in the rows differ $(\mathrm{P}<0.05)$ by $\mathrm{F}$ test for type of corn; means followed by different lowercase letters in the rows differ $(\mathrm{P}<0.05)$ by Tukey test for grinding degree.

$\mathrm{C}$ - type of corn; G - grinding degree; DMI - dry matter intake, CPI - crude protein intake; EEI - ether extract intake; NDFI - neutral detergent fiber intake; MMI - minera matter intake; NFCI - non-fibrous carbohydrate intake; TDNI - total digestible nutrient intake.

Table 6 - Growth performance, coefficient of variation (CV, \%) and error probability (P) of heifers during lactation

\begin{tabular}{|c|c|c|c|c|c|c|c|c|c|}
\hline \multirow[t]{2}{*}{ Variable } & \multicolumn{2}{|c|}{ Type of corn } & \multicolumn{3}{|c|}{ Grinding degree } & \multirow[t]{2}{*}{ CV \% } & \multicolumn{3}{|c|}{ P-value } \\
\hline & Dent & Flint & 1 & 3 & 5 & & C & G & $\mathrm{C} \times \mathrm{G}$ \\
\hline iBW & 31.22 & 31.38 & 31.33 & 30.00 & 30.94 & - & - & - & - \\
\hline fBW & 48.08 & 48.60 & 49.45 & 46.86 & 47.08 & 33.5 & 0.156 & 0.122 & 0.655 \\
\hline ADG g/day & 281 & 287 & 302 & 281 & 269 & 35.1 & 0.106 & 0.520 & 0.476 \\
\hline IHW cm & 15 & 14 & $14 a b$ & $13 b$ & $16 \mathrm{a}$ & 46.6 & 0.103 & 0.015 & 0.619 \\
\hline $\mathrm{CH} \mathrm{cm}$ & 17 & 15 & 16 & 14 & 18 & 39.5 & 0.179 & 0.122 & 0.651 \\
\hline TP $\mathrm{cm}$ & 19 & 21 & $25 a$ & $17 b$ & 19ab & 43.6 & 0.102 & 0.027 & 0.280 \\
\hline FC & 2.18 & 2.31 & 2.22 & 2.24 & 2.48 & 30.2 & 0.064 & 0.068 & 0.635 \\
\hline
\end{tabular}

Means followed by different lowercase letters in the rows differ $(\mathrm{P}<0.05)$ by $\mathrm{F}$ test for grinding degree.

C - corn type; G - grinding degree; iBW - Initial body weight; fBW - final body weight ; ADG - average daily gain; IWH - increase in wither height; CH - increase in croup height; TI - increase in thoracic perimeter; FC - feed conversion. 
Brisola \& Lucci (1998), who found a $7.25 \mathrm{~cm}$ wither height increase for animals of the same age group in a 42-day period, on the basis of a differentiated weaning system (35 days of life). Mean increase in croup height was $16 \mathrm{~cm}$. Maize type did not exert any effect on increase in thoracic perimeter, whose mean was $20.7 \mathrm{~cm}$, a value consistent with that found by Schalch et al. (2001), $18 \mathrm{~cm}$, in a study involving pure Holstein calves receiving full cream milk and concentrate with 15,30 and $45 \%$ of corn replacement for citrus pulp during 70 days.

Aita et al. (2006) did not find any differences in the chest circumference of Jersey calves aged 56 days and fed full cream milk or surrogate with 10,15 or $20 \%$ ether extract in dry matter.

Grinding degree exerted a significant effect on thoracic perimeter $(\mathrm{P}<0.05)$, with a higher value for concentrate milled at $1 \mathrm{~mm}(25.2 \mathrm{~cm})$, as compared with that milled at $3 \mathrm{~mm}(17.1 \mathrm{~cm})$; on the other hand, there was no difference when compared with the $5 \mathrm{~mm}$ grinding degree $(19.8 \mathrm{~cm})$.

Neither corn type nor grinding degree interfered with feed conversion, with an average of 2.25. Although DMI was greater for heifers receiving flint corn and weight gain was similar between calves fed flint and dent corn, that was not enough to promote significant differences in feed conversion (2.18 x 2.31, respectively); thus, there was a $6.5 \%$ trend of superiority to flint corn. Young suckling calves showed lower average feed conversion. Aita et al. (2006) found a mean feed conversion of 2.16 for weaned calves and Schalch et al. (2001) found a mean value of 1.13 for calves fed mashed concentrate.

There was no significant interaction $(\mathrm{P}>0.05)$ between corn type $\times$ grinding degree for the average digestibility coefficients. Regarding the average dry matter digestibility, there was an effect $(\mathrm{P}<0.05)$ resulting from corn type and grinding degree (Table 7 ).
The DMD for dent corn was lower $(\mathrm{P}<0.05)$ as compared with flint corn, with values of $78.9 \%$ and $84.3 \%$, respectively. Regarding grinding degree, the highest value $(\mathrm{P}<0.05)$ was found for heifers fed corn ground in $5 \mathrm{~mm}$ mesh sieves (84.2\%); on the other hand, those fed concentrate milled at $1 \mathrm{~mm}$ and $3 \mathrm{~mm}$ showed proportional values of $79.1 \%$ and $78.1 \%$, respectively. Higher digestibility values were expected as dent corn facilitates the digestion of starch by microorganisms and fine grinding increases the area of contact of rumen microorganisms on starch; in turn, a higher grinding degree seems not to hinder ruminal digestibility as it promotes greater dry matter intake and improves digestive efficiency.

Likewise in this study, a DMD value of $85.1 \%$ was found by Gonsalves Neto et al. (2008) for suckling calves fed mashed concentrate. Pires et al (2008) did not find any differences in DMD for coarsely ground corn (70.5\%) as compared with finely ground corn (67\%).

Type and degree of grinding corn $(\mathrm{P}>0.05)$ had no effect on CPD, EED, NDFD or NFCD. In a study involving Hereford calves, Freitas et al. (2003) found values of 66.30 for DMD and $73.4 \%$ for NDFD. In a study involving purebred Holstein calves fed $90 \%$ concentrate, on a dry matter basis, Burger et al. (2000) found values of 75.0\%, 45.3\% and $86.1 \%$ for DMD, and NDFD and EED, respectively.

The TDN values did not significantly $(\mathrm{P}>0.05)$ differ for type and degree of corn. The average TDN values were $116.95 \%$, regardless of corn types and grinding degrees. Gonsalves Neto et al. (2008) found TDN values of $89.3 \%$ for mashed concentrate and $90.7 \%$ for pelleted concentrate. It is noteworthy that TDN values above $100 \%$ for calves fed milk usually result from the high-fat content of milk and high nutrient intake values.

Table 7 - Digestibility and dietary content coefficients of total digestible nutrients (g/kg), coefficients of variation (CV, \%) and probability $(\mathrm{P})$ of heifers

\begin{tabular}{|c|c|c|c|c|c|c|c|c|c|}
\hline \multirow[t]{2}{*}{ Variable } & \multicolumn{2}{|c|}{ Type of corn } & \multicolumn{3}{|c|}{ Grinding degree } & \multirow[t]{2}{*}{ CV \% } & \multicolumn{3}{|c|}{ P-value } \\
\hline & Dent & Flint & 1 & 3 & 5 & & C & G & $\mathrm{C} \times \mathrm{G}$ \\
\hline DMD & 789B & 843A & 791b & $781 \mathrm{~b}$ & 842a & 9.4 & 0.033 & 0.017 & 0.657 \\
\hline CPD & 799 & 856 & 815 & 834 & 833 & 9.6 & 0.105 & 0.120 & 0.927 \\
\hline EED & 954 & 936 & 963 & 935 & 937 & 6.5 & 0.149 & 0.131 & 0.319 \\
\hline NDFD & 659 & 734 & 680 & 710 & 699 & 13.7 & 0.268 & 0.155 & 0.687 \\
\hline NFCD & 845 & 801 & 828 & 849 & 792 & 7.4 & 0.107 & 0.204 & 0.847 \\
\hline TDN & 1136 & 1203 & 1143 & 1191 & 1174 & 11.3 & 0.244 & 0.126 & 0.701 \\
\hline
\end{tabular}

Means followed by different uppercase letters in the rows differ $(\mathrm{P}<0.05)$ by $\mathrm{F}$ test for type of corn; means followed by different lowercase letters in the rows differ $(\mathrm{P}<0.05)$ by the Tukey test for grinding degree.

C - type of corn; G - grinding degree; DMD - dry matter digestibility; CPD - crude protein digestibility; EED - ether extract digestibility; NDFD - neutral detergent fiber digestibility; NFCD - non-fibrous carbohydrates digestibility; TDN - total digestible nutrients. 


\section{Conclusions}

Flint corn stimulates higher intake and dry matter digestibility by heifers, but these differences are not sufficient for animals to have a better performance. Grinding degrees of 3 and $5 \mathrm{~mm}$ promote higher dry matter intake, whereas that of $5 \mathrm{~mm}$ promotes greater dry matter digestibility. Yet, these results are not consistent with improved animal performance.

\section{References}

AITA, M.F.; FISCHER, V.; STUMPF, W. Efeitos dos níveis de extrato etéreo no sucedâneo do leite sobre o desenvolvimento corporal de bezerros Jersey. Revista Brasileira de Zootecnia, v.35, n.1, p.193-202, 2006.

ASSOCIATION OF OFFICIAL ANALYTICAL CHEMISTS - AOAC. Official methods of analysis. Washington, 1990. v.2. 1278p.

BAGALDO, A.R.; VAZ PIRES, A.; MEYER, P.M. et al. Efeitos do uso de sucedâneo do leite e milho processado no desempenho de bezerros da raça holandesa até o desmame. Acta Scientiarum, v.23, n.4, p.967-972, 2001.

BITTAR, C.M.M.; FERREIRA, L.S.; SANTOS, F.A.P. et al. Desempenho e desenvolvimento do trato digestório superior de bezerros leiteiros alimentados com concentrado de diferentes formas físicas. Revista Brasileira de Zootecnia, v.38, n.8, p.1561-1567, 2009.

BRISOLA, M.L.; LUCCI, C.S. Desaleitamento de bezerros com emprego de soja integral extrusada na mistura iniciadora. Brazilian Journal of Veterinary Research and Animal Science, v.35, n.3, p.134-138, 1998.

BURGER, P.J.; PEREIRA, J.C.; SILVA, J.F.C. et al. Consumo e digestibilidade aparente total e parcial em bezerros holandeses alimentados com dietas contendo diferentes níveis de concentrado. Revista Brasileira de Zootecnia, v.29, n.1, p.206-214, 2000.

CAMPOS, O.F. Criação de bezerros até a desmama. In: PEIXOTO, A.M.; MOURA J.C.; FARIA, V.P. (Eds.) Bovinocultura leiteira: fundamentos da exploração racional. 3.ed. Piracicaba: FEALQ, 2000. 581p.

CUNHA, D.N.F.; CAMPOS, O.F.; PEREIRA, J.C. et al. Desempenho, variáveis fisiológicas e comportamento de bezerros mantidos em diferentes instalações: época chuvosa. Revista Brasileira de Zootecnia, v.36, n.4, p.1140-1146, 2007.

DETMANN, E.; VALADARES FILHO, S.C.; PINA, D.S. et al. Prediction of the energy value of cattle diets based on chemical composition of the feeds under tropical conditions. Animal Feed Science and Technology, v.143, p.124-147, 2008.

DETMANN, E.; VALADARES FILHO, S.C. On the estimation of non-fibrous carbohydrates in feeds and diets. Arquivo Brasileiro de Medicina Veterinária e Zootecnia, v.62, n.4, p.980-984, 2010.

DHIMAN, T.R.; ZAMAN, M.S.; McQUEEN, I.S. et al. Influence of corn processing and frequency of feeding on cow performance. Journal of Dairy Science, v.85, p.217-226, 2002.
FRANKLIN, S.T.; AMARAL-PHILIPS, D.M.; JACKSON, J.A. et al. Health and performance of Holstein calves that suckled or were hand-fed colostrums and were fed one of three physical forms of starter. Journal of Dairy Science, v.86, n.6, p.2145-2153, 2003.

FREITAS, S.G.; PATINO, H.O.; MÜHLBACH, P.R.F. et al. Efeito da suplementação de bezerros com blocos multinutricionais sobre a digestibilidade, o consumo e os parâmetros ruminais. Revista Brasileira de Zootecnia, v.32, n.6, p.1508-1515, 2003.

GONSALVES NETO, J.; SILVA, F.F.; BONOMO, P. et al. Desempenho de bezerros da raça Holandesa alimentados com concentrado farelado ou peletizado. Revista Brasileira de Saúde e Produção animal, v.9, n.4, p.726-733. 2008.

LEISMEISTER, K.E.; HEINRICHS, A.J. Effects of corn processing on growth characteristics, rumen development, and rumen parameters in neonatal dairy calves. Journal of Dairy Science, v.87, p.3439-3450, 2004.

NATIONAL RESEARCH COUNCIL - NRC. Nutrient requirements of dairy cattle. 6.rev.ed. Washington, D.C.: National Academy Press, 1989. 242p.

NATIONAL RESEARCH COUNCIL - NRC. Nutrient requirements of beef cattle. 7.ed. Washington D.C.: National Academy Press, 1996. 248p.

NATIONAL RESEARCH COUNCIL - NRC. Nutrient requirements of dairy cattle. 7.ed. Washington, D.C.: National Academic Press, 2001. 381p.

NUSSIO, C.M.B.; SANTOS, F.A.P.; PIRES. A.V. et al. Fontes de amido de diferentes degradabilidades e sua substituição por polpa de citrus em dietas para vacas leiteiras. Acta Scientiarum, v.24, n.4, p.1079-1086, 2002.

NUSSIO, C.M.B.; SANTOS, F.A.P.; ZOPOLLATTO, M. et al. Processamento de milho (floculado vs. laminado a vapor) e adição de monensina para bezerras leiteiras, pré e pós-desmama precoce. Revista Brasileira de Zootecnia, v.32, n.1, p.229-239, 2003.

PHILLIPPEAV, C.; MICHALET-DOREAU, B. Influence of maize genotype on rate ruminal starch degradation. Animal Feed Science and Technology, v.68, p.25- 35, 1997.

PIRES, A.V.; SUSIN, I.; SANTOS, F.A.P. et al. Efeito de fontes e formas de processamento do amido sobre o desempenho e o metabolismo do nitrogênio em vacas Holandesas em lactação. Revista Brasileira de Zootecnia, v.37, n.8, p.1456-1462, 2008.

ROHR, K.; DAENICKE, R. Nutritional effects on the distribution of live weight as gastrointestinal tract fill and tissue components in growing cattle. Journal of Animal Science, v.58, p.753-765, 1984.

SANTOS, F.A.P.; CARMO, C.A.; BITTAR, C.M.M. et al. Milho com diferentes graus de moagem em combinação com polpa cítrica peletizada ou casca de soja para vacas leiteiras no terço médio da lactação. Revista Brasileira de Zootecnia, v.36, n.4, p.1183-1191, 2007 (supl.).

SCHALCH, F.J.; SCHALCH, E.; ZANETTI, M.A. et al. Substituição do milho em grão moído pela polpa cítrica na desmama precoce de bezerros leiteiros. Revista Brasileira de Zootecnia, v.30, n.1, p.280-285. 2001.

SILVA, D.J.; QUEIROZ, A.C. Análises de alimentos: métodos químicos e biológicos. Viçosa, MG: UFV, 2002. 235p. 